\title{
Metacognitive Learning Approach in Affecting Students' Self-Regulated Learning in Writing Course
}

\author{
Abdul Halim¹, Sofia Ulfa Eka Hadiyanti² \\ DOI: $10.35445 /$ alishlah.v13i2.571
}

\begin{tabular}{l} 
Article Info \\
\hline Keywords: \\
EFL students; \\
learner autonomy; \\
SRL; \\
writing
\end{tabular}

Kata kunci:

Siswa EFL; otonomi pelajar;

$S R L$;

penulisan

\begin{abstract}
The research aimed to investigate the effect of metacognitive instruction on students' self-regulated learning (SRL) writing for Indonesian EFL students to have appropriate grammar and meaningful learning experiences. The methodology used was a quasi-experimental design. The research participants were 50 students from the University of Muhammadiyah East Kalimantan (UMKT) English department who took a writing course. The participants were divided into the experimental group that was taught with metacognitive instruction. In contrast, although the same teacher taught the control group and had similar learning materials, the teacher did not use metacognitive instruction. The data was taken through pre-test and post-test and analyzed through independent t-test with statistics tool SPSS. The results showed that the experimental group has a higher SRL score with significant results in overall score even though there is one component that is different from previous studies, namely knowledge of cognition. Some suggestions were proposed.
\end{abstract}

\begin{abstract}
Abstrak
Penelitian ini bertujuan untuk mengetahui pengaruh pembelajaran metakognitif pada pembelajaran mandiri siswa (self-regulated learning) dalam pembelajaran menulis (writing) untuk siswa EFL di Indonesia agar dapat menggunakan grammar yang baik dan mendapatkan pengalaman belajar yang bermakna. Metodologi yang digunakan adalah desain kuasi eksperimental. Partisipan penelitian ini adalah 50 orang mahasiswa Jurusan Bahasa Inggris Universitas Muhammadiyah Kalimantan Timur (UMKT) yang mengambil mata kuliah writing. Partisipan dibagi menjadi dua kelompok, kelompok eksperimen $(n=25)$ dan kelompok kontrol $(n=25)$. Kelompok eksperimen diajar dengan instruksi metakognitif. Sebaliknya, kelompok kontrol, meskipun diajar oleh guru yang sama dan memiliki materi pembelajaran yang serupa, namun guru tersebut tidak menggunakan pembelajaran metakognitif. Pengambilan data dilakukan melalui pre-test dan post-test dan dianalisa dengan independent t-test dengan SPSS. Hasil penelitian menunjukkan bahwa kelompok eksperimen memiliki skor SRL yang lebih tinggi dengan hasil yang signifikan secara keseluruhan skor meskipun ada satu komponen yang berbeda dengan penelitian sebelumnya yaitu pengetahuan kognisi. Beberapa saran diajukan.
\end{abstract}

\footnotetext{
${ }^{1}$ Universitas Muhammadiyah Kalimantan Timur, Indonesia

National Dong Hwa University, Taiwan

Email:ah918@umkt.ac.id

${ }^{2}$ Universitas Muhammadiyah Kalimantan Timur, Indonesia
} 


\section{INTRODUCTION}

Successful communication relies heavily on the ability to comprehend the language and to produce the language. When either skill has failed to be carried out by a speaker or a language user, the communication process may have been delivered ineffectively. Therefore, the process is very vital. Writing as one of the academic skills needs more prominent efforts. It needs different properties and complexity from other language skills to deliver the speaker's messages more effectively (Widiati \& Cahyono, 2001). Otherwise, communication would fail to stand. In such a situation, the teacher should notice the importance of having an appropriate approach for the students to learn writing.

However, in Indonesia, where English is a foreign language, English writing is still a problem (Ghufron \& Ermawati, 2018; Mustafa et al., 2016; Widiati, 2002; Widiati \& Cahyono, 2001). Not only was the writing course/subject complex from the students' perspective, but the students might not also know what to do and where to start. They seemed to be lost even with guidance from the teacher. Students writing in some levels of education did not meet the satisfactory results (Megawati, 2012; Widiati \& Cahyono, 2001), although some attempts had been made through various approaches, including the current trend of technology and social media (Fithriani et al., 2019; Halim et al., 2019). Similar to what others have faced in writing courses, the researcher also encountered problems related to instructional approaches that could be the best for the classrooms.

One of the ways that can be done to cope with this problem is by elevating the students' autonomy and self-efficacy so that the students can adapt well to the writing process's difficulty, and their awareness of self-learning would improve as well as their self-confidence. The independence of learning would affect the success of their learning process.

Getting the students to learn and use the writing strategies is not enough. The goal of educating the students is to learn to learn, which means they should learn to be autonomous (Kobayashi, 2018). When learner autonomy is well established, the students have a big chance to succeed in their academic life. The process where the students get involved actively in learning with their metacognition, behavior, and motivation is called self-regulated learning (SRL) (Zimmerman, 2008). The students who possess SRL would be able to evaluate their learning actively. They would be able to plan, monitor, and evaluate the purpose of their learning and the final goal of the learning process (Kobayashi, 2018; Zimmerman, 2008).

Thus, meanwhile, most studies were focusing on listening skills. The purpose of study was to investigate the effect of metacognitive instructions in students' self-regulated learning (SRL) writing of Indonesian EFL students for one semester at a private university in East Kalimantan, Indonesia. Therefore, some research questions came up: Do metacognition instructions improve students' SRL in writing courses?

The SRL in writing was elaborated in some subsections, and therefore some sub-research questions followed; how do the instructions affect the students' self-efficacy?; how do the instructions affect the students' knowledge of cognition; how do the instructions affect the students' awareness of metacognition; and how do the instructions affect the students' strategic behavior?

Some studies related to SRL have been completed with almost similar motives, i.e., finding out how students can be the 'master' for the process of their independent learning (Zimmerman, 2008). Such a process has to be one of the main aims for educators because the students will learn independently. Their ability to self-motivate and solve immediate problems would develop as well.

A few years ago, a case study of SRL in writing had been conducted with one participant of the research (Kartika, 2015). The research purpose was to analyze SRL's effect on the academic writing of a student in Australia. The results showed that there were improvements in ordinary writing skills as well as writing marks. However, the study left some points for further investigation, namely a more extended research period and further investigation of its impact on motivation. Another perspective has also been inspected on SRL towards writing. A survey study was completed on 
investigating the students' attitudes to SRL strategies (Abadikhah et al., 2018). The results indicated that most students in Iran have moderate to slightly high self-regulation in learning. A survey study of SRL was done (Ariyanti et al., 2018). The study is aimed at surveying EFL students' SRL in writing. The finding indicated that 19 percent of the research participants were well-regulated students, making them have better accomplishments than others. Meanwhile, 70 percent of the participants were at a moderate level, and the other 11 percent were poorly self-regulated, leaving the gap of how to improve the SRL in writing.

Metacognitive strategies have been a research interest for many researchers. A claim was induced that not many of them investigate the pedagogical practice of improving one's capacity to think metacognitively (Ellis et al., 2014). In contrast, metacognition is one of the keys to the success of the operational stage (child's development of Piaget's Cognition Theory). The metacognitive strategies are also the foundation for high-achieving students at developing their skills in many aspects of academics (Iwai, 2011).

In understanding the importance of metacognitive strategies, knowing the difference between cognitive and metacognitive strategies is needed. In modest definition, cognitive strategies are used when they function to obtain knowledge in specific ways. Meanwhile, metacognitive strategies occur when one monitors what he/she has learned and what is needed to learn (Smith et al., 2007). It has pedagogical implications if the teacher wants to see the students succeed academically. The teacher also needs to address metacognitive strategies to stimulate learning beyond the conventional way of teaching. Traditionally, the teacher gives a bunch of learning materials without helping the students analyze how to learn well. By doing so, students will be self-regulated in learning. They would learn effortlessly in applying the appropriate learning process as they are likely to succeed (Iwai, 2011; Kobayashi, 2018; Santisi et al., 2014; Smith et al., 2007).

\section{METHODS}

The study used a quasi-experimental design (Roever \& Phakiti, 2017). The participants were 50 students, with 25 students in the experiment group and 25 in the control group. The experiment group was treated with a metacognitive learning approach, and the control group was not given such an approach. All participants were freshmen at the English Education department at a private university in East Kalimantan. The study was conducted in three months duration.

The data were collected through a pre-test and post-test with the Self-Regulated Learning in Writing Questionnaire. The questionnaire used for pre-test and post-test is the same as it was to measure their self-regulated learning scale. The questionnaire was developed from an adaptation of the Self-Regulated Learning in Listening Questionnaire with some aspects of self-regulated learning: Self-Efficacy, Knowledge of Cognition, Awareness of Metacognition, and Strategic Behavior (Kobayashi, 2018). The questionnaire items were set with a Likert scale from 1 (not at all true of me) to 5 (very true of me). Before collecting the data, the questionnaire was checked for construct validity with an expert, a university professor. Once the construct validity was done, the researcher continued with face validity. Some 20 students were invited to join a pilot test for reliability test and to use statistical analysis software, Cronbach alpha showed .889 , indicating the items were reliable.

The data collection process was run in a period of eleven active weeks of the semester term. In the first week, a pre-test was given. From the second to the tenth week, the subjects in group A were given treatment in the writing course with metacognitive instruction. The other group studied the same learning materials but not with metacognitive instruction. The final data was collected through the post-test. The data were analyzed with an independent T-test by using IBM Statistical Package for Social Sciences (SPSS) program.

\section{FINDINGS AND DISCUSSION}

The research results are described by presenting the results of the impact of metacognitive learning instruction on SRL. There are four components of SRL that are assessed: Self-efficacy, 
knowledge of cognition, awareness of metacognition, and strategic behavior. As explained in the method section, there were two groups involved in this study, the control and treatment groups. Therefore, the data were presented by considering these items.

\section{Metacognitive strategies on self-efficacy}

Following are the results of the two groups, both the control group and the treatment group. The first group is the control group. In the following table is the Self-Efficacy Control Group:

Table 1. Control group's self-efficacy

\begin{tabular}{|c|c|c|c|c|c|c|}
\hline & $\mathrm{N}$ & Minimum & Maximum & Sum & Mean & Std. Deviation \\
\hline A1 & 25 & 2 & 3 & 66 & 2.64 & .490 \\
\hline A2 & 25 & 2 & 4 & 78 & 3.12 & .666 \\
\hline A3 & 25 & 2 & 4 & 76 & 3.04 & .611 \\
\hline Valid N (listwise) & 25 & & & & & \\
\hline
\end{tabular}

Table 2. Self-efficacy of the treatment group

\begin{tabular}{|c|c|c|c|c|c|c|}
\hline & $\mathrm{N}$ & Minimum & Maximum & Sum & Mean & Std. Deviation \\
\hline A1 & 25 & 2 & 4 & 84 & $3 \cdot 36$ & .810 \\
\hline A2 & 25 & 2 & 5 & 97 & 3.88 & 1.013 \\
\hline A3 & 25 & 2 & 4 & 89 & $3 \cdot 56$ & .583 \\
\hline Valid N (listwise) & 25 & & & & & \\
\hline
\end{tabular}

Remark:

A1: I think I can get a satisfactory grade in writing (writing) class

A2: I think I can understand the primary materials in writing class

A3: I think I can do the assignments and tests well in the writing class

Of the 25 respondents, in general, they showed valid data. In general, the control group showed the post-test results below that of the treatment group with a score of 2.9 compared to the treatment group who scored 3.6. Based on the collected data, the treatment group showed a higher mean score, at all aspects such as item A1, which shows the value of 3.36 , item A2 with a value of 3.88 , and item $\mathrm{A} 3$ with a value of 3.56 .

Table 3. Mean difference Self-Efficacy

\begin{tabular}{|c|c|c|c|c|c|}
\hline & Group & $\mathrm{N}$ & Mean & Std. Deviation & $\begin{array}{l}\text { Std. Error } \\
\text { Mean }\end{array}$ \\
\hline (SRL) Self-Efficacy score & Control Group & 25 & 2.9360 & .33650 & .06730 \\
\hline & Experiment Group & 25 & 3.6000 & .52520 & .10504 \\
\hline
\end{tabular}

Table 4. Self-efficacy t-test

Independent Samples Test

\begin{tabular}{|c|c|c|c|c|c|c|c|c|c|c|}
\hline & \multicolumn{2}{|c|}{$\begin{array}{c}\text { Levene's Test for Equality of } \\
\text { Variances }\end{array}$} & \multicolumn{7}{|c|}{ t-test for Equality of Means } \\
\hline & & \multirow[b]{2}{*}{$F$} & \multirow[b]{2}{*}{ Sig. } & \multirow[b]{2}{*}{$t$} & \multirow[b]{2}{*}{$d f$} & \multirow[b]{2}{*}{ Sig. (2-tailed) } & \multirow{2}{*}{$\begin{array}{c}\text { Mean } \\
\text { Difference }\end{array}$} & \multirow{2}{*}{$\begin{array}{l}\text { Std. Error } \\
\text { Difference }\end{array}$} & \multicolumn{2}{|c|}{$\begin{array}{c}\text { 95\% Confidence Interval of the } \\
\text { Difference }\end{array}$} \\
\hline & & & & & & & & & Lower & Upper \\
\hline (SRL) Self-Efficacy score & $\begin{array}{l}\text { Equal variances } \\
\text { assumed }\end{array}$ & 3.947 & .053 & -5.323 & 48 & .000 & .66400 & .12475 & -.91483 & -.41317 \\
\hline & $\begin{array}{l}\text { Equal variances not } \\
\text { assumed }\end{array}$ & & & -5.323 & 40.863 & .000 & .66400 & .12475 & -.91596 & -.41204 \\
\hline
\end{tabular}

To see how significant the results of the two groups' self-efficacy, an independent t-test was carried out. Table 4 and Table 5 show the self-efficacy results for the two groups with significant results $\mathrm{p}=0.000$ with a significant level of sig $>=0.05$.

\section{Metacognitive strategies on knowledge of cognition}

Table 5 and Table 6 below show the cognition knowledge of the control and treatment groups. In general, of the three items (B1, B2, and B3), the control and treatment groups did not significantly 
differ in the mean (control group: 3.07; experiment group: 3.33).

Table 5. Knowledge of Cognition of Control Group

\begin{tabular}{lccccc}
\hline & $\mathrm{N}$ & Minimum & Maximum & Mean & Std. Deviation \\
\hline B1 & 25 & 2.00 & 4.00 & 3.0800 & .64031 \\
B2 & 25 & 2.00 & 4.00 & 2.9600 & .67577 \\
B3 & 25 & 2.00 & 4.00 & 3.1600 & .62450 \\
Valid N (listwise) & 25 & & & & \\
\hline
\end{tabular}

Table 6. Knowledge of Cognition of Experiment Group

\begin{tabular}{lccccc}
\hline & N & Minimum & Maximum & Mean & Std. Deviation \\
\hline B1 & 25 & 2.00 & 5.00 & 3.8800 & .72572 \\
B2 & 25 & 2.00 & 4.00 & 2.9600 & .67577 \\
B3 & 25 & 2.00 & 4.00 & 3.1600 & .62450 \\
Valid N (listwise) & 25 & & & & \\
\hline
\end{tabular}

Remark:

B1: I can evaluate my learning progress

B2: I have clear goals when I study with a particular learning strategy

B3: I am aware of what learning strategies that I use

Table 7. Mean difference knowledge of cognition

\begin{tabular}{llcccc}
\hline & \multicolumn{1}{c}{ Group } & N & Mean & Std. Deviation & $\begin{array}{c}\text { Std. Error } \\
\text { Mean }\end{array}$ \\
\hline (SRL) Knowledge of & Control Group & 25 & 3.0720 & .38136 & .07627 \\
cognition score & Experiment Group & 25 & 3.3360 & .36387 & .07277 \\
\hline
\end{tabular}

Table 9. Knowledge of cognition t-test

\begin{tabular}{|c|c|c|c|c|c|c|c|c|c|c|}
\hline \multicolumn{11}{|c|}{ Independent Samples Test } \\
\hline & & \multicolumn{2}{|c|}{$\begin{array}{c}\text { Levene's Test for Equality of } \\
\text { Variances }\end{array}$} & \multicolumn{7}{|c|}{ t-test for Equality of Means } \\
\hline & & \multirow[b]{2}{*}{$\mathrm{F}$} & \multirow[b]{2}{*}{ Sig. } & \multirow[b]{2}{*}{$t$} & \multirow[b]{2}{*}{ df } & \multirow[b]{2}{*}{ Sig. (2-tailed) } & \multirow{2}{*}{$\begin{array}{c}\text { Mean } \\
\text { Difference }\end{array}$} & \multirow{2}{*}{$\begin{array}{l}\text { Std. Error } \\
\text { Difference }\end{array}$} & \multicolumn{2}{|c|}{$\begin{array}{l}95 \% \text { Confidence Interval of the } \\
\text { Difference }\end{array}$} \\
\hline & & & & & & & & & Lower & Upper \\
\hline $\begin{array}{l}\text { (SRL) Knowledge of } \\
\text { cognition score }\end{array}$ & $\begin{array}{l}\text { Equal variances } \\
\text { assumed }\end{array}$ & .160 & .691 & -2.504 & 48 & .016 & -26400 & .10542 & -.47596 & -05204 \\
\hline & $\begin{array}{l}\text { Equal variances not } \\
\text { assumed }\end{array}$ & & & -2.504 & 47.895 & .016 & -.26400 & .10542 & -.47597 & -.05203 \\
\hline
\end{tabular}

When testing the hypothesis with a t-test, the results as shown in table 8 and table 9 did not show a significant difference between the treatment group and the test group with a sig value (2-tail) $=0.016$ with a level of sig $>=0.005$.

\section{Metacognitive strategies on awareness of metacognition}

Compared to the previous items, the items on metacognition awareness were seen to have a mean difference between the control group and the treatment group. In the control group, the mean score was 3.0, with the lowest score of 2.9 on items $\mathrm{C}_{4}$ and $\mathrm{C}_{5}$ and the highest on items $\mathrm{C} 2$ and C6 with a score of 3.2. Meanwhile, the mean score for the treatment group is at point 3.7, the lowest score in item $\mathrm{C}_{5}$ with a score of 3.6 and the highest on item $\mathrm{C} 6$ with a score of 4.2. 
Table 9. Awareness of metacognition of the control group

\begin{tabular}{lccccc}
\hline & N & Minimum & Maximum & Mean & Std. Deviation \\
\hline C1 & 25 & 2.00 & 4.00 & 3.0000 & .57735 \\
C2 & 25 & 2.00 & 4.00 & 3.2800 & .67823 \\
C3 & 25 & 2.00 & 4.00 & 3.1200 & .66583 \\
C4 & 25 & 2.00 & 4.00 & 2.9600 & .53852 \\
C5 & 25 & 2.00 & 4.00 & 2.9200 & .57155 \\
C6 & 25 & 3.00 & 4.00 & 3.2800 & .45826 \\
Valid N (listwise) & 25 & & & & \\
\hline
\end{tabular}

Table 10. Awareness of metacognition of experiment group

\begin{tabular}{lccccc}
\hline & $\mathrm{N}$ & Minimum & Maximum & Mean & Std. Deviation \\
\hline $\mathrm{C} 1$ & 25 & 2.00 & 5.00 & 3.7200 & .73711 \\
$\mathrm{C} 2$ & 25 & 2.00 & 5.00 & 3.8000 & .64550 \\
$\mathrm{C} 3$ & 25 & 3.00 & 5.00 & 3.6400 & .63770 \\
$\mathrm{C} 4$ & 25 & 3.00 & 5.00 & 3.6800 & .62716 \\
$\mathrm{C} 5$ & 25 & 3.00 & 5.00 & 3.6000 & .64550 \\
$\mathrm{C6}$ & 25 & 3.00 & 5.00 & 4.2000 & .64550 \\
& & & & & \\
Valid N (listwise) & 25 & & & & \\
\hline
\end{tabular}

Remark:

C1: I think it is important to understand my strengths and weaknesses as a student

C2: It is essential for me to know which learning strategies are the most effective and when to use them

C3: It is important that I monitor how well I write

C4: To improve my writing skills, I set my own study goals

C5: I ask myself regularly whether my learning progress is following the targets I have set

C6: After finishing my writing assignment, I try to evaluate my performance

Table 11. Mean difference awareness of metacognition

\begin{tabular}{lccccc}
\hline & Group & N & Mean & Std. Deviation & $\begin{array}{c}\text { Std. Error } \\
\text { Mean }\end{array}$ \\
\hline (SRL) Awareness of & Control Group & 25 & 3.0960 & .24406 & .04881 \\
metacognition score & Experiment Group & 25 & 3.7720 & .26851 & .05370 \\
\hline
\end{tabular}

Table 12. Awareness of metacognition t-test

\begin{tabular}{|c|c|c|c|c|c|c|c|c|c|c|}
\hline \multicolumn{11}{|c|}{ Independent Samples Test } \\
\hline & & \multicolumn{2}{|c|}{$\begin{array}{c}\text { Levene's Test for Equality of } \\
\text { Variances }\end{array}$} & \multicolumn{7}{|c|}{ t-test for Equality of Means } \\
\hline & & \multirow[b]{2}{*}{$\mathrm{F}$} & \multirow[b]{2}{*}{ Sig. } & \multirow[b]{2}{*}{$t$} & \multirow[b]{2}{*}{ df } & \multirow[b]{2}{*}{ Sig. (2-tailed) } & \multirow{2}{*}{$\begin{array}{l}\text { Mean } \\
\text { Difference }\end{array}$} & \multirow{2}{*}{$\begin{array}{l}\text { Std. Error } \\
\text { Difference }\end{array}$} & \multicolumn{2}{|c|}{$\begin{array}{c}\text { 95\% Confidence Interval of the } \\
\text { Difference }\end{array}$} \\
\hline & & & & & & & & & Lower & Upper \\
\hline $\begin{array}{l}\text { (SRL) Awareness of } \\
\text { metacognition score }\end{array}$ & $\begin{array}{l}\text { Equal variances } \\
\text { assumed }\end{array}$ & .007 & .933 & -9.315 & 48 & .000 & .67600 & .07257 & .82192 & .53008 \\
\hline & $\begin{array}{l}\text { Equal variances not } \\
\text { assumed }\end{array}$ & & & -9.315 & 47.569 & .000 & .67600 & .07257 & .82195 & .53005 \\
\hline
\end{tabular}

The overall mean score of items of C1-C6 from groups A and B was calculated. The experiment group exhibits a higher mean score of 3.77 than the control group of 3.09, as shown in Table 11. As shown in Table 12, T-test was performed to see the significance of the differences between the two groups, which showed significant results with a sig (2-tailed) $=0.000$ at $\operatorname{sig}=0.05$. 


\section{Metacognitive strategies on the strategic behavior}

The final component of SRL is strategic behavior. This component is about how a person carries out specific strategies for self-learning. When identifying each item, the trend of both groups shows a different outcomes. The tendency of the experiment group to outperform the control group has indicated that they have better strategic behavior (see table 13 for the control group and table 14 for the experiment group).

Table 13. The strategic behavior control group

\begin{tabular}{lccccc}
\hline & N & Minimum & Maximum & Mean & $\begin{array}{c}\text { Std. } \\
\text { Deviation }\end{array}$ \\
\hline D1 & 25 & 2.00 & 4.00 & 3.2400 & .59722 \\
D2 & 25 & 2.00 & 4.00 & 2.8400 & .68799 \\
D3 & 25 & 2.00 & 4.00 & 3.2800 & .67823 \\
D4 & 25 & 3.00 & 4.00 & 3.4800 & .50990 \\
D5 & 25 & 2.00 & 4.00 & 3.2400 & .52281 \\
Valid N (listwise) & 25 & & & & \\
& & & & & \\
\hline
\end{tabular}

Table 14. Strategic behavior experiment group

\begin{tabular}{lccccc}
\hline & N & Minimum & Maximum & Mean & Std. Deviation \\
\hline D1 & 25 & 3.00 & 5.00 & 3.9600 & .61101 \\
D2 & 25 & 2.00 & 5.00 & 3.6400 & .70000 \\
D3 & 25 & 3.00 & 4.00 & 3.7200 & .45826 \\
D4 & 25 & 3.00 & 4.00 & 3.4800 & .50990 \\
D5 & 25 & 3.00 & 5.00 & 4.1200 & .66583 \\
Valid N (listwise) & 25 & & & & \\
\hline
\end{tabular}

Remark:

D1: To improve my writing skills, I regularly read written samples in English and practice

D2: To improve my writing skills, I write English words and expressions repeatedly to remember them.

D3: To improve my writing skills, I write my ideas on a notebook as an outline for developing paragraphs.

D4: To improve my writing skills, I learned to study languages in English.

D5: To improve my writing skills, I learned the basic structure of a sentence

Table 15. Mean difference in strategic behavior

\begin{tabular}{llrrrr}
\hline & Group & N & Mean & Std. Deviation & \multicolumn{2}{c}{ Mean } \\
\hline (SRL) Strategic behavior & Control Group & 25 & 3.2160 & .26407 & .05281 \\
score & Experiment Group & 25 & 3.7840 & .27641 & .05528 \\
\hline
\end{tabular}

Table 16. Strategic behavior t-test

\begin{tabular}{|c|c|c|c|c|c|c|c|c|c|c|}
\hline \multicolumn{11}{|c|}{ Independent Samples Test } \\
\hline & & \multicolumn{2}{|c|}{$\begin{array}{c}\text { Levene's Test for Equality of } \\
\text { Variances }\end{array}$} & \multicolumn{7}{|c|}{ t-test for Equality of Means } \\
\hline & & \multirow[b]{2}{*}{$\mathrm{F}$} & \multirow[b]{2}{*}{ Sig. } & \multirow[b]{2}{*}{$t$} & \multirow[b]{2}{*}{ df } & \multirow[b]{2}{*}{ Sig. (2-tailed) } & \multirow{2}{*}{$\begin{array}{c}\text { Mean } \\
\text { Difference }\end{array}$} & \multirow{2}{*}{$\begin{array}{l}\text { Std. Error } \\
\text { Difference }\end{array}$} & \multicolumn{2}{|c|}{$\begin{array}{l}95 \% \text { Confidence Interval of the } \\
\text { Difference }\end{array}$} \\
\hline & & & & & & & & & Lower & Upper \\
\hline $\begin{array}{l}\text { (SRL) Strategic behaviour } \\
\text { score }\end{array}$ & $\begin{array}{l}\text { Equal variances } \\
\text { assumed }\end{array}$ & .116 & .734 & -7.429 & 48 & .000 & $\cdot .56800$ & .07645 & -.72172 & -.41428 \\
\hline & $\begin{array}{l}\text { Equal variances not } \\
\text { assumed }\end{array}$ & & & -7.429 & 47.900 & .000 & -.56800 & .07645 & -.72173 & -.41427 \\
\hline
\end{tabular}

In total, the mean score in the control group was 3.2. This value is lower than the treatment group, with a value of 3.8. Furthermore, statistical tests were carried out to see the level of significance using the t-test. The test results show the value of $\mathrm{p}=0.000$ at the level of $\operatorname{sig}>=0.05$. Thus, it can be said that there is a significant difference. 
Tabel 17. Mean difference of overall score

\begin{tabular}{llcccc}
\hline & Group & $\mathrm{N}$ & Mean & Std. Deviation & $\begin{array}{c}\text { Std. Error } \\
\text { Mean }\end{array}$ \\
\hline Overall SRL Score & Control Group & 25 & 3.0972 & .14499 & .02900 \\
& Experiment Group & 25 & 3.6684 & .12562 & .02512 \\
\hline
\end{tabular}

Tabel 18. Overall score

Independent Samples Test

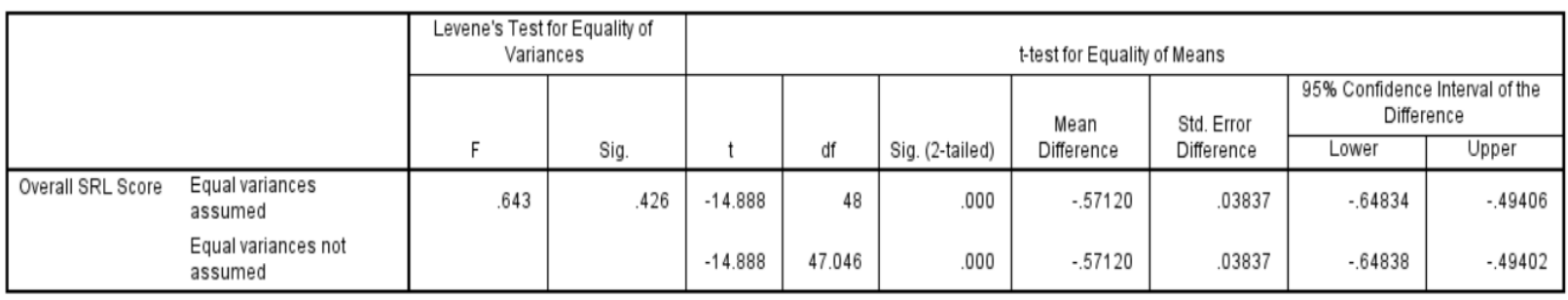

In general, we can see the mean score results between the control and treatment groups with different values, namely 3.09 for the control group and 3.67 for the treatment group. It shows the difference in the post-test results of the two groups in an overall view of all items combined. Then, the t-test was carried out to see the significance of this value. The t-test results showed a significant value, namely $\mathrm{p}=0.000$ with a sig level $>=0.05$.

In general, the four components of SRL are evaluated: Self-efficacy, knowledge of cognition, awareness of metacognition, and strategic behavior, showing promising results. Where overall, the treatment group had a higher SRL value. Even though, when viewed from each component, one component does not show significant results, namely knowledge of the technician. The two groups showed an average difference. However, the t-test of the group's findings did not show any significant results. Nevertheless, apart from these points, in general, the treatment group showed better results.

Self-regulated learning is believed to have a good impact on students' learning achievement. Hence, the better SRL possessed by the students, the higher of a possibility of better learning achievement. This is supported by several studies that have shown promising results (Abadikhah et al., 2018; Ariyanti et al., 2018; Kobayashi, 2018). Therefore, it is essential to see what can influence this factor, such as a teaching process that uses a metacognitive approach. This metacognitive strategy refers to the awareness of each student in thinking and learning, what they think and how they think related to learning situations (Goh, 2008). The application of learning strategies with this approach has a tangible impact on the SRL level of the students involved as participants in this study. It can be seen from the results presented in the research findings section; almost every aspect has increased significantly. Self-efficacy is the first component of SRL analyzed in this study. The study's findings showed a significant mean difference between the two groups; those who received learning materials with metacognitive strategy and those without a metacognitive strategy approach. It complements the findings from previous studies that motivation and self-efficacy can also be improved (Kartika, 2015).

Cognition knowledge is a component that does not get a significant difference from this study. One way to look at this situation is to look at it is from the mean score. The mean score for cognition knowledge as one of the components of SRL was 3.0 for the control group and 3.3 for the treatment group. It indicates that both groups have a moderate level of cognitive knowledge. This finding is consistent with previous research, where entry-level students had a more moderate SRL level (Abadikhah et al., 2018). By looking at the overall significant development of the learning experiment using the metacognitive strategy approach to student self-regulated learning, this can positively impact the development of student creativity (Hargrove, 2013). The evidence of the findings in this study shows that a positive change in the SRL that the participants own increases significantly and 
can bring excellent opportunities for all participants. Several other studies have been conducted before in which SRL can impact motivation and increase learning outcomes (Ariyanti et al., 2018; Kartika, 2015; Kobayashi, 2018; Zimmerman, 2008).

\section{CONCLUSION}

Teaching and learning techniques that use metacognitive strategies can significantly affect students' self-regulated learning. Of the four components: Self-efficacy, knowledge of cognition, awareness of metacognition, and strategic behavior, there are three that have a significant impact from experiments, namely self-efficacy, metacognition awareness, and strategic behavior. Meanwhile, knowledge of cognition did not have a significant effect even though, on average, there was an increase in the overall mean score. However, the level of knowledge of cognition is still in a moderate position, which is typical in early grade students, according to findings in previous studies. The advantage of increasing SRL is that it is closely related to several aspects that support student learning outcomes. Some of them are increased motivation and academic success. Motivation is an essential part of the learning process. Students will be able to participate more actively and be more involved in any activity or activity that the instructor or teacher has designed. That way, they open the opportunity for academic success and provide maximum results.

The researcher provides suggestions for several parties who might benefit from this research based on the explanation above. First, teaching with this metacognitive strategy approach increases SRL for practitioners who teach in class. Thus, using this approach to be implemented in the classroom might help solve one of the many problems the school faces. Second, for researchers, this research was conducted in a higher education setting. There is still a gap to see whether the results obtained will be consistent if it is carried out with different backgrounds and student situations. Likewise, a more detailed explanation of the results of our findings can be carried out using qualitative methods to obtain further confirmation.

\section{REFERENCES}

Abadikhah, S., Aliyan, Z., \& Talebi, S. H. (2018). EFL students' attitudes towards self-regulated learning strategies in academic writing. Issues in Educational Research, 28(1), 1-17.

Ariyanti, A., Fitriana, R., \& Pane, W. S. (2018). Self-Regulated Learning in Writing of EFL Learners. Indonesian Journal of English Language Teaching and Applied Linguistics, 3(1), 155-166. https://doi.org/10.21093/IJELTAL.V3I1.170

Ellis, A. K., Denton, D. W., \& Bond, J. B. (2014). An Analysis of Research on Metacognitive Teaching Strategies. Procedia - Social and Behavioral Sciences, 116, 4015-4024. https://doi.org/10.1016/j.sbspro.2014.01.883

Fithriani, R., Dewi, U., Daulay, S. H., Salmiah, M., \& Fransiska, W. (2019). Using Facebook in EFL Writing Class: Its Effectiveness from Students' Perspective. KnE Social Sciences, 2019, 634645. https://doi.org/10.18502/kss.v3i19.4892

Ghufron, M. A., \& Ermawati, S. (2018). The strengths and weaknesses of cooperative learning and problem-based learning in EFL writing class: Teachers and students' perspectives. International Journal of Instruction, 11(4), 657-672. https://doi.org/10.12973/iji.2018.11441a

Halim, A., Khatimah, K., Rachman, D., Lubis, A. A., Sunarti, S., Puspita, R. H., \& Rahmawati, Y. (2019). Exploring efl students' experiecens on online-based writing portfolio. Acitya Journal of Teaching and Education, 1(1), 1-9. http://journals.umkt.ac.id/index.php/acitya/article/view/200

Iwai, Y. (2011). The Effects of Metacognitive Reading Strategies: Pedagogical Implications for $\begin{array}{llll}\text { EFL/ESL Teachers. } & \text { Reading, } & \text { 11(2), } & \text { 150-159. }\end{array}$ http://readingmatrix.com/articles/april_2011/iwai.pdf

Kartika, H. D. (2015). A Learner's Self-Regulated Learning in Writing. IJEE (Indonesian Journal of English Education), 2(2), 120-131. https://doi.org/10.15408/ijee.v2i2.3085

Kobayashi, A. (2018). Investigating the effects of metacognitive instruction in listening for EFL 


$\begin{array}{lllll}\text { learners. Journal of } & \text { Asia } & \text { TEFL, } & 15(2), & 310-328 .\end{array}$
https://doi.org/10.18823/asiatefl.2018.15.2.1.310

Megawati, F. (2012). Comic Strips:a Study on the Teaching of Writing Narrative Texts To Indonesian Efl Students. TEFLIN Journal, 23(2), 183-205. https://doi.org/10.15639/teflinjournal.v23i2/183-205

Mustafa, F., Kirana, M., \& Bahri Ys, S. (2016). Errors in EFL writing by junior high students in Indonesia. International Journal of Research Studies in Language Learning, 5(5). https://doi.org/10.5861/ijrsll.2016.1366

Roever, C., \& Phakiti, A. (2017). Quantitative methods for Second Language Research. In Quantitative methods for Second Language Research. Taylor and Francis. https://doi.org/10.4324/9780203067659

Santisi, G., Magnano, P., Hichy, Z., \& Ramaci, T. (2014). Metacognitive Strategies and Work Motivation in Teachers: An Empirical Study. Procedia - Social and Behavioral Sciences, 116, 1227-1231. https://doi.org/10.1016/j.sbspro.2014.01.373

Smith, K. S., Rook, J. E., \& Smith, T. W. (2007). Increasing Student Engagement Using Effective and Metacognitive Writing Strategies in Content Areas. Preventing School Failure: Alternative Education for Children and Youth, 51(3), 43-48. https://doi.org/10.3200/psfl.51.3.43-48

Widiati, U. (2002). Problems with Peer Response of Writing-as-a-Process Approach in an EFL Writing Classroom. In Jurnal Ilmu Pendidikan (Vol. 9, Issue 3, pp. 188-199).

Widiati, U., \& Cahyono, B. Y. (2001). the Teaching of Efl Writing in the Indonesian Context : the State of the Art. Jurnal Ilmu Pendidikan, 13(3), 139-150. http://journal.um.ac.id/index.php/jip/article/viewFile/40/357

Zimmerman, B. J. (2008). Investigating self-regulation and motivation: Historical background, methodological developments, and future prospects. American Educational Research Journal, 45(1), 166-183. https://doi.org/10.3102/0002831207312909 